\title{
Effect of Fibre and Microsilica Incorporation on High Temperature Resistance of Cementitious Complex Binder
}

\author{
Regina KALPOKAITÉ-DIČKUVIENE் * , Kristina BRINKIENE், \\ Jūratė Č́̇SIENĖ, Algis MAKŠTYS
}

Laboratory of Materials Research and Testing, Lithuanian Energy Institute, Breslaujos 3, LT-44403 Kaunas, Lithuania

Received 21 September 2010; accepted 22 October 2010

\begin{abstract}
Complex binder reinforced with microfibre produced from waste catalyst was investigated. Influence of 1,3 and $5 \%$ of fibre as well as $5 \%$ of microsilica on the mechanical strength of complex binder after thermal treatment at 600,800 and $1000{ }^{\circ} \mathrm{C}$ temperature was analyzed. According to the experimental results reinforcement with $1 \%$ of fibre had advantage on mechanical strength of complex binder up to $800^{\circ} \mathrm{C}$, meanwhile $5 \%$ of fibre resulted in the lowest values of strength in all firing temperature range. The strength of dry samples was improved with microsilica incorporation. But above $800^{\circ} \mathrm{C}$ temperature cold crushing strength as well as thermal shrinkage of binder reinforced with fibre and microsilica was lower in comparison with ordinary complex binder at $1000^{\circ} \mathrm{C}$.

Keywords: microfibre, cold crushing strength, binder, XRD, shrinkage, density.
\end{abstract}

\section{INTRODUCTION}

Various kinds of additions create special properties of fresh mix and hardened concrete. The use of the ultrafine waste of the production of ferroalloys and crystalline silicon as active microfiller for structural and refractory concretes solves many important problems, i. e. fabrication of high-strength, super-dense and long-life concrete as well as reinforced concrete structures, reduction of energy consumption in the production of concrete and, if necessary, saving a cement [1]. In accordance with $[1,2]$ the efficiency of microsilica additives in the nanotechnology of cement composites is explainable by the fact that the particles of $\mathrm{SiO}_{2}$ react with calcium hydrate and form calcium hydrosilicate. This causes a substantial decrease (up to $30 \%$ ) in the content of pores, as well as due to the distribution of the fine pores the paste become more homogeneous and dense [2]. However silica causes the concrete to have more brittle structure [3, 4], but at the same time it improves fibre dispersion and interfacial interaction between fibres and cement phases $[5,6]$. Different types of fibres such as steel, glass and ceramic, carbon, synthetic and organic fibres are used in industry to reinforce cementitious materials. Addition of glass and ceramic fibres into concrete increases the energy absorption capacity of concrete and provides more ductile and tough structure $[7,8]$. Introduction of steel fibres into a refractory provides three-dimensional volumetric strengthening and an increase in material endurance as well as a reduction in shrinkage during heat treatment $[3,9]$. This leads to a significant increase in crack resistance and impact strength $[9,10]$.

For manufacture of refractory concretes hydraulic, chemical, ceramic as well as complex binders are used. According to [11] addition of microsilica (5 wt $\% \div 8 \mathrm{wt} \%$ ) increases density and mechanical strength of refractory concrete with liquid glass binder. Meanwhile $4 \%$ of

*Corresponding author. Tel.: +370-37-401984; fax: +370-37-351271.

E-mail address: regina@mail.lei.lt (R. Dičkuvienè) microsilica reduces thermal endurance of the material. Moreover rheological properties of fresh concrete paste vary a lot with increase of microsilica content from $4 \%$ up to $6 \%$. As a result $5 \%$ of microsilica was found to be optimal for refractory concrete.

It was determined [12] that mechanical strength and thermal shock resistance of complex binder itself was better as compared with traditional liquid glass-based binder. But formation of macro cracks was observed after exposure at elevated temperatures.

According to our previous results [13], microfibre, produced from recycled waste catalyst (zeolite), transforms to stable mullite phase at $900^{\circ} \mathrm{C}$ after $2 \mathrm{~h}$ and could be used for complex binder reinforcement. Moreover fibre didn't destruct after aging in complex binder [14]. Furthermore formation and growth of reaction products on the surface of the fibre was observed after heat treatment at $1000^{\circ} \mathrm{C}$.

The object of this work is to investigate the effect of fibre and microsilica incorporation on high temperature resistance as well as mechanical strength of cementitious complex binder in the temperature range up to $1000^{\circ} \mathrm{C}$.

\section{EXPERIMENTAL}

The cementitious complex binder used in this study consists of calcium aluminate cement, metallurgical slag waste and sodium liquid glass. Chemical composition and properties of components had been listed in [13]. Production of microfibre from waste catalyst (zeolites) as well as micro structural analysis was depicted elsewhere in detail [14]. In this study as-produced microfibre which is amorphous material, was used. Complex binder itself and reinforced with $1 ; 3 ; 5 \mathrm{wt} \%$ of as-produced microfibre was tested. $5 \%$ of microsilica was used in this study and according to [11] this is the optimal content for refractory with complex binder. Chemical composition of microsilica (RW Silicium GmbH, Germany) is presented in Table 1. 
According to [12] $\mathrm{w} / \mathrm{c}=0.3$ ratio ensures workability of mix without loss of mechanical strength. In this study due to incorporation of microfiber, water to cement ratio was increased up to $\mathrm{w} / \mathrm{c}=0.35$ and it was constant for all eight mixes, which were prepared (Table 2). Samples of dimensions of $(20 \times 20 \times 20) \mathrm{mm}$ for cold crushing strength were formed and cured in moulds for 3 days at above the water and 4 days at the ambient temperature of $(20 \pm 2){ }^{\circ} \mathrm{C}$. After curing all samples were dried at $100^{\circ} \mathrm{C}$ until they reached constant weight. Each group of samples were exposed to $600^{\circ} \mathrm{C}, 800^{\circ} \mathrm{C}$ and $1000^{\circ} \mathrm{C}$ for $3 \mathrm{~h}$ [15] and cooled to room temperature before testing.

Cold crushing strength test was performed on dried and fired samples according to EN ISO 8895:2006. Bulk density and relative shrinkage was estimated according to standard LST EN 993-1:2001 and LST EN 1094-6:2001 respectively. Expanded uncertainty of measurement corresponding to a coverage probability of less than $95 \%$ is $\pm 1.7 \%$ for cold crushing strength, $\pm 2.4 \%$ for thermal expansion and $\pm 0.06 \%$ for density test.

X-ray diffraction (XRD) patterns were obtained using $\mathrm{Cu}-\mathrm{K}_{\alpha}$ radiation (DRON-UM1) source to identify the existing phases by the commercial Search Match program.

Table 1. Chemical composition and physical properties of microsilica

\begin{tabular}{|c|c|c|c|c|}
\hline \multicolumn{2}{|c|}{$\begin{array}{c}\text { Chemical composition, } \\
\text { wt } \%\end{array}$} & $\mathrm{pH}$ & $\begin{array}{l}\text { Loss on } \\
\text { ignition, \% }\end{array}$ & $\begin{array}{l}\text { Density, } \\
\mathrm{kg} / \mathrm{m}^{3}\end{array}$ \\
\hline $\mathrm{SiO}_{2}$ & 96.06 & \multirow{9}{*}{7.5} & \multirow{9}{*}{0.44} & \multirow{9}{*}{200} \\
\hline $\mathrm{Al}_{2} \mathrm{O}_{3}$ & 0.20 & & & \\
\hline $\mathrm{Fe}_{2} \mathrm{O}_{3}$ & 0.05 & & & \\
\hline $\mathrm{C}$ & 0.60 & & & \\
\hline $\mathrm{CaO}$ & 0.25 & & & \\
\hline $\mathrm{MgO}$ & 0.40 & & & \\
\hline $\mathrm{K}_{2} \mathrm{O}$ & 1.20 & & & \\
\hline $\mathrm{Na}_{2} \mathrm{O}$ & 0.10 & & & \\
\hline $\mathrm{SO}_{3}$ & 0.35 & & & \\
\hline
\end{tabular}

Table 2. The composition of mixes (wt $\%$ )

\begin{tabular}{|c|c|c|c|}
\hline $\begin{array}{c}\text { Mix } \\
\text { code }\end{array}$ & $\begin{array}{c}\text { Complex } \\
\text { binder } \\
\text { content }\end{array}$ & $\begin{array}{c}\text { Fibre } \\
\text { content }\end{array}$ & $\begin{array}{c}\text { Microsilica } \\
\text { content }\end{array}$ \\
\hline $0 \mathrm{~F}$ & 100 & 0 & 0 \\
\hline $1 \mathrm{~F}$ & 99 & 1 & 0 \\
\hline $3 \mathrm{~F}$ & 97 & 3 & 0 \\
\hline $5 \mathrm{~F}$ & 95 & 5 & 0 \\
\hline $0 \mathrm{~F}+\mathrm{MS}$ & 95 & 0 & 5 \\
\hline $1 \mathrm{~F}+\mathrm{MS}$ & 94 & 1 & 5 \\
\hline $3 \mathrm{~F}+\mathrm{MS}$ & 92 & 3 & 5 \\
\hline $5 \mathrm{~F}+\mathrm{MS}$ & 90 & 5 & 5 \\
\hline
\end{tabular}

\section{RESULTS AND DISCUSSION}

Test methods of cold crushing strength and thermal shrinkage are used to determine high temperature resistance of cementitious complex binder. Fig. 1 presents the results of investigation of the effect of microfibre content on cold crushing strength (CCS) of complex binder with and without microsilica addition as a function of temperature. CCS data expressed as a comparative ratio between CCS values for reinforced complex binder and non-doped one are summarized in Tables 3 and 4.

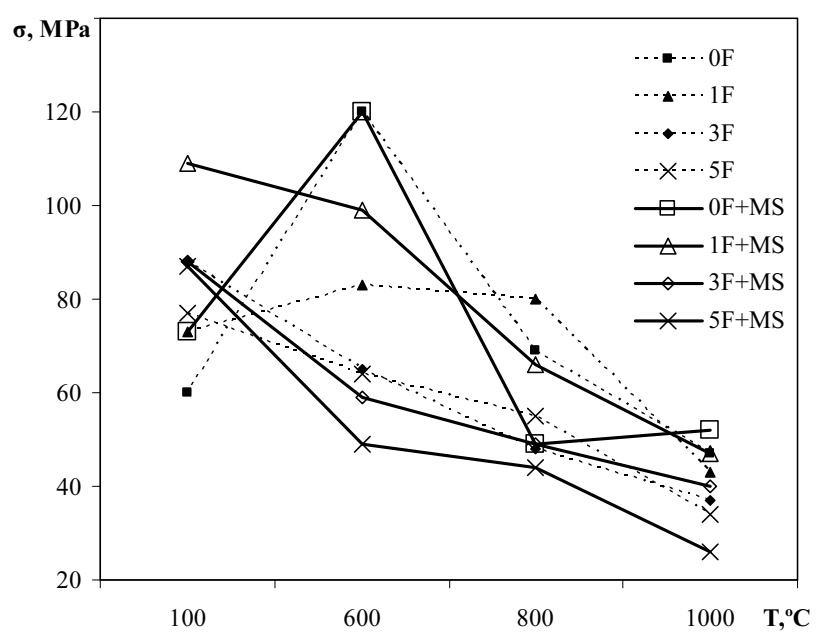

Fig. 1. Cold crushing strength of complex binder reinforced with fibre (F) and microsilica (MS) as a function of temperature

It was observed that reinforcement with fibre leads to the increase of CCS of complex binder from $22 \%$ up to $47 \%$ at $100{ }^{\circ} \mathrm{C}$ (Table 3 ) and it is in good agreement with literature $[9,16]$. Moreover addition of microsilica increased CCS of complex binder up to $22 \%$ (Table 4 ). This effect is more evident for complex binder reinforced with $1 \%$ of fibre and shows maximum strength increase up to $49 \%$ at this temperature. Only CCS of $(3 \mathrm{~F}+\mathrm{MS})$ sample remained unchanged. The maximum compressive strength $(109 \mathrm{MPa})$ was measured for the sample reinforced both with $1 \%$ of fibre and microsilica $(1 \mathrm{~F}+\mathrm{MS})$ at $100{ }^{\circ} \mathrm{C}$ (Fig. 1) and comparing with ordinary complex binder (0F) the strength increased up to $82 \%$. Similarly the growth of density was observed for all samples at $100^{\circ} \mathrm{C}$, but it was less than $2 \%$ (Fig. 2).

Table 3. Effect of fibre content on cold crushing strength of complex binder

\begin{tabular}{|c|c|c|c|c|}
\hline CCS ratio & $100{ }^{\circ} \mathrm{C}$ & $600{ }^{\circ} \mathrm{C}$ & $800{ }^{\circ} \mathrm{C}$ & $1000{ }^{\circ} \mathrm{C}$ \\
\hline$\frac{\sigma(1 \mathrm{~F})}{\sigma(0 \mathrm{~F})}$ & $+22 \%$ & $-31 \%$ & $+16 \%$ & $-9 \%$ \\
\hline$\frac{\sigma(3 \mathrm{~F})}{\sigma(0 \mathrm{~F})}$ & $+47 \%$ & $-46 \%$ & $-30 \%$ & $-21 \%$ \\
\hline$\frac{\sigma(5 \mathrm{~F})}{\sigma(0 \mathrm{~F})}$ & $+28 \%$ & $-47 \%$ & $-20 \%$ & $-28 \%$ \\
\hline
\end{tabular}

Table 4. Effect of microsilica addition on cold crushing strength of microfibre reinforced complex binder

\begin{tabular}{|c|c|c|c|c|}
\hline CCS ratio & $100{ }^{\circ} \mathrm{C}$ & $600{ }^{\circ} \mathrm{C}$ & $800{ }^{\circ} \mathrm{C}$ & $1000{ }^{\circ} \mathrm{C}$ \\
\hline$\frac{\sigma(0 \mathrm{~F}+\mathrm{MS})}{\sigma(0 \mathrm{~F})}$ & $+22 \%$ & $0 \%$ & $-29 \%$ & $-11 \%$ \\
\hline$\frac{\sigma(1 \mathrm{~F}+\mathrm{MS})}{\sigma(1 \mathrm{~F})}$ & $+49 \%$ & $+19 \%$ & $-18 \%$ & $+9 \%$ \\
\hline$\frac{\sigma(3 \mathrm{~F}+\mathrm{MS})}{\sigma(3 \mathrm{~F})}$ & $0 \%$ & $-9 \%$ & $0 \%$ & $+8 \%$ \\
\hline$\frac{\sigma(5 \mathrm{~F}+\mathrm{MS})}{\sigma(5 \mathrm{~F})}$ & $+13 \%$ & $-23 \%$ & $-20 \%$ & $-24 \%$ \\
\hline
\end{tabular}


After calcinations at $600^{\circ} \mathrm{C}$ the highest CCS was estimated for ordinary complex binder $(0 \mathrm{~F})$ and for complex binder with microsilica addition (0F+MS) (Fig. 1). The increase of CCS up to $14 \%$ was observed for (1F) mix as well (Fig. 1), meanwhile other samples showed reduction of strength. It was determined that addition of $1 \%$ of fibre into the mix reduces the strength of complex binder up to $31 \%$ (Table 3 ). Although addition of microsilica into that mix improves results of strength up to $19 \%$ (Table 4), but it was still lower than of ordinary complex binder (Fig. 1). According to the results at $600{ }^{\circ} \mathrm{C}$ (Table 3 ) higher content of fibre reduces CCS more than $30 \%$ and still further decreases with presence of microsilica (Table 4). In Lau and Soro studies $[9,16]$ the drop of mechanical strength up to $50 \%$ for fibre reinforced material at $600{ }^{\circ} \mathrm{C}$ was attributed to the dehydration of matrix. According to [12] dehydration of not reinforced ordinary complex binder takes place in the temperature range $580{ }^{\circ} \mathrm{C}-640^{\circ} \mathrm{C}$ and is accompanied by micro cracking and porosity formation. That explains reduction of bulk density of all samples up to $4 \%$ (Fig. 2) at $600{ }^{\circ} \mathrm{C}$.

XRD patterns of fibre reinforced complex binder didn't show formation of new crystalline phases (Fig. 3, a), only for binder with microsilica $\mathrm{SiO}_{2}$ peak (S) was identified (Fig. 3, b) at $600^{\circ} \mathrm{C}$. Furthermore samples with microsilica addition shrank approximately three times in comparison with the ordinary binder (Fig. 4) whereas relative shrinkage of binder reinforced with fibre was only $2.4 \%$.

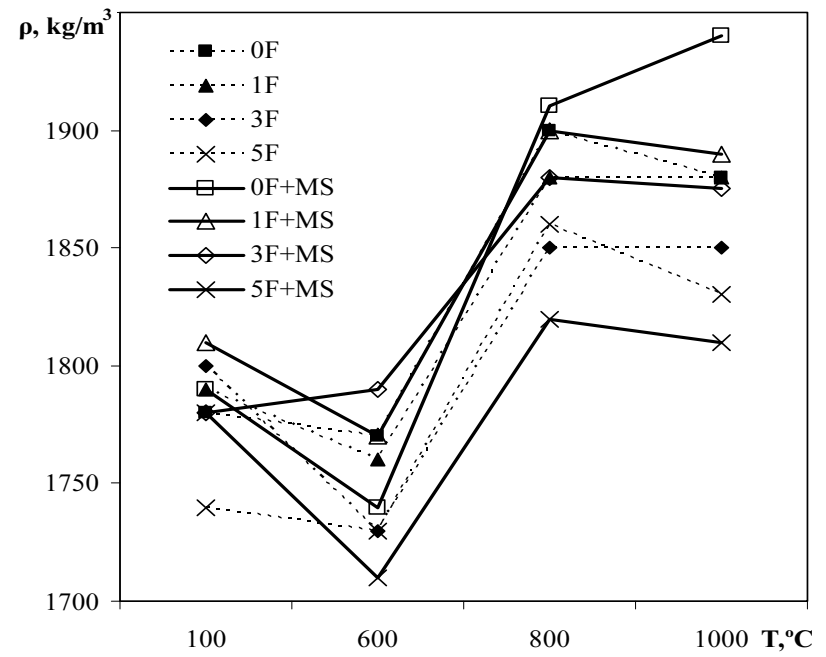

Fig. 2. Density of complex binder reinforced with fibre $(\mathrm{F})$ and microsilica (MS) as a function of temperature

Despite microsilica or fibre content bulk density of all samples increased approximately $7 \%$ with increasing temperature up to $800{ }^{\circ} \mathrm{C}$ (Fig. 2), whereas mean relative shrinkage $4.5 \%$ was obtained (Fig. 4). The highest shrinkage $(5.64 \%)$ was determined for binder reinforced with only $1 \%$ of fibre $(1 \mathrm{~F})$. Contrary, the crushing strength of (1F) samples was still relatively high $(80 \mathrm{MPa})$ comparing with ordinary complex binder (F0) (Fig. 1). However higher content of fibre and microsilica addition lead the drop of mechanical strength of binder at $800^{\circ} \mathrm{C}$ (Tables 3,4). According to data of XRD analysis it could be attributed to the formation of crystalline gehlenite $\left(\mathrm{C}_{2} \mathrm{AS}\right)$ phase (Fig. 3, a) through possible metakaolinite reaction with $\beta$-CS [17]. Reduction of $\mathrm{CCS}$ at $800^{\circ} \mathrm{C}$ was mentioned by others [2, 4] as well.

At $1000{ }^{\circ} \mathrm{C}$ temperature only $\mathrm{C}_{2} \mathrm{AS}, \mathrm{CA}_{2}$ and $\mathrm{CA}$ were identified (Fig. 3) and slight reduce up to $1.5 \%$ of density for all samples was determined (Fig. 2) as well as further reduction of CCS (Fig. 1). Mechanical strength of samples reinforced with fibre or silica was still lower than ordinary complex binder; however microsilica addition to the mixes with $1 \%$ and $3 \%$ of fibre enhanced CCS up to $9 \%$ (Table 4). Comparing results of dried and annealed at $1000^{\circ} \mathrm{C}$ samples of fibre reinforced complex binder (Fig. 1) it was estimated that CCS value reduced less than $65 \%$, instead of $80 \%$ declared in $[9,16]$.

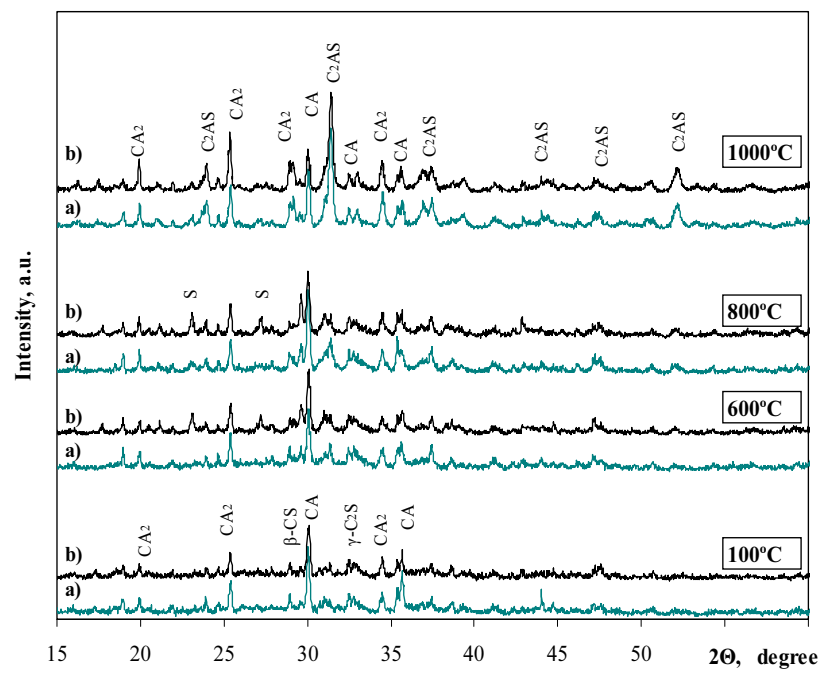

Fig. 3. XRD patterns of complex binder reinforced with: a $-5 \%$ of fibre $(5 \mathrm{~F}), \mathrm{b}-5 \%$ of fibre and $5 \%$ of microsilica $(5 \mathrm{~F}+\mathrm{MS})$, heat treated at $100^{\circ} \mathrm{C}, 600^{\circ} \mathrm{C}, 800^{\circ} \mathrm{C}$ and $1000{ }^{\circ} \mathrm{C}$ for 3 hours

100

600

800

$1000 \mathbf{T},{ }^{\circ} \mathbf{C}$

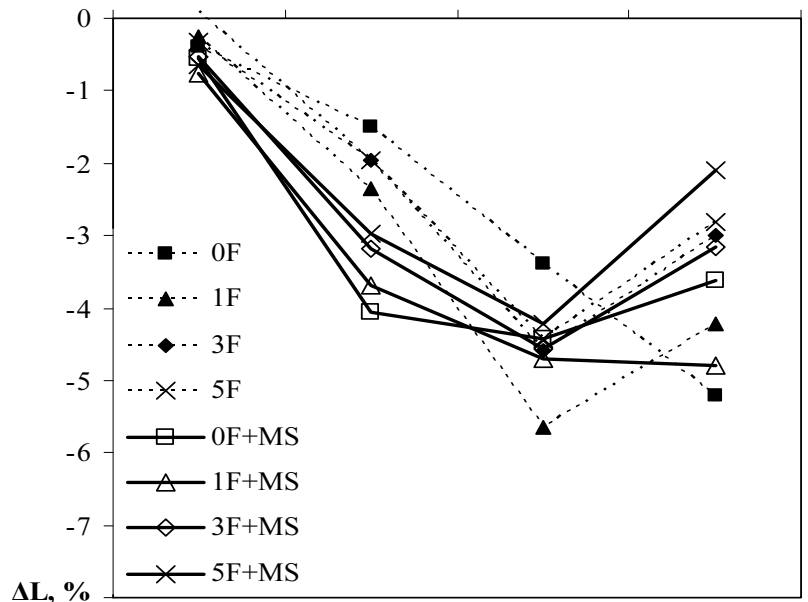

Fig. 4. Relative thermal shrinkage of complex binder reinforced with fibre (F) and microsilica (MS) as a function of temperature

The highest shrinkage (5.2\%) was measured for ordinary complex binder after heat treatment at $1000^{\circ} \mathrm{C}$. Microsilica incorporation reduced thermal shrinkage up to $1 / 3$ as well as reinforcement with fibre showed reduction of shrinkage from $1 / 5$ up to $2 / 5$ with $1 \%$ and $5 \%$ of fibre respectively (Fig. 4). 


\section{CONCLUSIONS}

The effect of microfibre and microsilica incorporation on cold crushing strength and thermal shrinkage of complex binder seems to be dependent on amount of additives and temperature level. Experimental results showed the growth of cold crushing strength (CCS) for dry samples: reinforcement with fibre increased CCS of ordinary complex binder up to $47 \%$ meanwhile addition of only microsilica - up to $22 \%$ at $100{ }^{\circ} \mathrm{C}$.

After treatment at $600{ }^{\circ} \mathrm{C}$ only samples with microsilica had the same strength as not reinforced complex binder, meanwhile samples doped with fibre and microsilica showed up to two times lower results.

Increase of CCS up to $16 \%$ was obtained at $800^{\circ} \mathrm{C}$ only for samples reinforced with $1 \%$ of fibre. Higher content of fibre as well as microsilica incorporation reduced strength of complex binder up to $30 \%$.

Heat treatment at $1000^{\circ} \mathrm{C}$ for $3 \mathrm{~h}$ determined further reduction of cold crushing strength of all mixes. Reinforcement with fibre reduced strength of ordinary complex binder up to $28 \%$ while microsilica addition only $11 \%$. Only samples reinforced with $1 \%$ of fibre and with microsilica had the same strength as ordinary complex binder.

Reduction of density of complex binder with increasing content of fibre was observed in all temperature range. Incorporation of microsilica reduced density of complex binder only at $600{ }^{\circ} \mathrm{C}$ meanwhile at other tested temperatures it was approximately the same or up to $3 \%$ higher. Approximately the same density results as ordinary complex binder showed samples reinforced both with $1 \%$ of fibre and $5 \%$ of microsilica in all temperature range.

Relative thermal shrinkage of ordinary complex binder was the lowest up to $800^{\circ} \mathrm{C}$ and the highest at $1000^{\circ} \mathrm{C}$. Reinforcement with fibre as well as incorporation of microsilica was favorable only at $1000^{\circ} \mathrm{C}$.

\section{Acknowledgments}

The authors are grateful to Research Council of Lithuania for financial support under nano-CSM Project.

\section{REFERENCES}

1. Pivinskii, Yu. E. Nanodisperse Silica and Some Aspects of Nanotechnologies in the Field of Silicate Materials Science. Part 2 Refractories and Industrial Ceramics 48 (6) 2007: pp. $28-38$.

2. Mohamed, S. M., Sayed, S. S. Effect of Silica Fume and Metakaolinite Pozzalana on the Performance of Blended Cement Pastes Against Fire Ceramics-Silikaty 51 (1) 2007: pp. $40-44$.

3. Koksal, F., Altun, F., Yigit, I., Sahin, Y. Combined Effect of Silica Fume and Steel Fibre on the Mechanical Properties of High Strength Concretes Construction and Building Materials 22 2008: pp. 1874-1880.

4. Behnood, A., Ziari, H. Effects of Silica Fume Addition and Water to Cement Ratio on the Properties of High-Strength Concrete after Exposure to High Temperatures Cement and Concrete Composites 30 2008: pp. 106-112.

5. Nili, M., Afroughsabet, V. The Effect of Silica Fume and Polypropylene Fibres on the Impact Resistance and Mechanical Properties of Concrete Construction and Building Materials 24 2010: pp. 927-933.

6. Sanchez, F., Ince, Ch. Microstructure and Macroscopic Properties of Hybrid Carbon Nanofibre/Silica Fume Cement Composites Composites Science and Technology 69 2009: pp. $1310-1318$.

7. Cerny, M., Glogar, P., Golias, V., Hruska, J., et al. Comparison of Mechanical Properties and Structural Changes of Continuous Basalt and Glass Fibres at Elevated Temperatures Ceramics-Silikaty 51 (2) 2007: pp. 82-88.

8. Ma, Y., Zhu, B., Tan, M. Properties of Ceramic Fibre Reinforced Cement Composites Cement and Concrete Research 35 2005: pp. 296-300.

9. Lau, A., Anson, M. Effect of High Temperature on High Performance Steel Fibre Reinforced Concrete Cement and Concrete Research 36 2006: pp. 1698-1707.

10. Kashcheev, I. D., Zemlyanoi, K. G., Podkopaev, S. A., et al. Use of Carbon Fibres in Refractory Materials Refractories and Industrial Ceramics 50 (10) 2009: pp. $15-19$.

11. Goberis, S., Pundienė, I., Špokauskas, A., Wala, T. Microsilica Tested as a Component for the Binder of a Medium-Cement Refractory Castable Refractories and Industrial Ceramics 44 (4) 2003: pp. 205-210.

12. Goberis, S., Antonovič, A. Refractory Fireclay Castable. Monograph. Vilnius: Technika, 2007: 360 p. (in Lithuanian).

13. Kalpokaitè-Dičkuvienè, R., Brinkienè, K., Čèsnienė, J. Investigation of Microfibre as Component of Cementitious Complex Binder Materials Science (Medžiagotyra) 15 (4) 2009: pp. 329-334.

14. Kalpokaitè-Dičkuvienė, R. Kèželis, R., Brinkienė, K., et al. Microstructure Analysis of Fibrous Material Manufactured by Plasma Spray Method Materials Science (Medžiagotyra) 15 (3) 2009: pp. 262-265.

15. Cultrone, G., et al. Carbonate and Silicate Phase Reactions during Ceramic Firing European Journal of Mineralogy 13 (3) 2001: pp. $621-634$.

16. Soro, J., Smith, A., Gault, Chr. Thermomechanical Characteristics of Calcium Aluminate Cement and Sand Tapes Prepared by Tape Casting Journal of the European Ceramic Society 26 2006: pp. 3799-3807.

17. Traore, K., Kabre, T.S., Blanchart, P. Gehlenite and Anorthite Crystallisation from Kaolinite and Calcite Mix Ceramics International 29 2003: pp. 377-383.

Presented at the National Conference "Materials Engineering '2010" (Kaunas, Lithuania, November 19, 2010) 